\title{
IMPLEMENTASI PENGEMBANGAN NILAI MORAL DAN AGAMA PADA ANAK USIA DINI MELALUI METODE KETELADANAN DI TK AL-MUHSIN
}

\author{
Fitriyah \\ IAIN Madura \\ Email: fitriyah261197@gmail.com
}

\begin{abstract}
The problem in this study is that there are children who have good moral religious values and the learning of moral religious values carried out by teachers is already applicable to students. This research was conducted to find out how the implementation of the development of moral religious values in early childhood aged 4-5 years through the exemplary method in Kindergarten Al-Muhsin Tagangser Daya, Pasean, Pamekasan This study uses qualitative research. The subject of this research is the classroom teacher. The informants of this study are the principal, class teacher. The method used in this study is observation, documentation and interviews. The results of this study indicate that the implementation of the development of moral religious values in early childhood through exemplary methods in Al-Muhsin Kindergarten includes memorizing short letters and daily prayers, practicing dhuha prayers conducted by the teacher by inviting students, polite courtesy in saying and behave towards older people, apologize when you do something wrong, say "help" in asking for help, say hello and shake hands when you meet.
\end{abstract}

Keywords: Development of Moral Religion Values, Exemplary Methods, Early Childhood

\begin{abstract}
Abstrak
Permasalahan dalam penelitian ini adalah terdapat anak yang memiliki nilai agama moral yang baik dan pembelajaran nilai agama moral yang dilakukan oleh guru sudah bersifat aplikatif terhadap siswa. Penelitian ini dilakukan untuk mengetahui bagaimana implementasi pengembangan nilai agama moral pada anak usia dini usia 4-5 tahun melalui metode keteladanan di TK Al-Muhsin Tagangser Daya, Pasean, Pamekasan Penelitian ini menggunakan jenis penelitian kualitatif. Subjek penelitian ini adalah guru kelas. Informan penelitian ini adalah kepala sekolah, guru pendamping kelas. Metode yang digunakan dalam penelitian ini adalah observasi, dokumentasi dan wawancara. Hasil penelitian ini menunjukkan bahwa implementasi pengembangan nilai agama moral pada anak usia dini melalui metode keteladanan di TK Al-Muhsin meliputi hafalan surat pendek dan doa-doa harian, praktek sholat dhuha yang dilakukan oleh guru dengan mengajak serta murid-muridnya, sopan santun dalam berkata dan bersikap kepada orang yang lebih tua,. meminta maaf ketika berbuat salah, mengucapkan "tolong" dalam meminta bantuan, mengucapkan salam dan berjabat tangan bila bertemu.
\end{abstract}

Kata kunci: Pengembangan Nilai Agama Moral, Metode Keteladanan, Anak Usia Dini 


\section{PENDAHULUAN}

Kebutuhan pendidikan kini cenderung meningkat. Pendidikan secara universal dapat dipahami sebagai upaya pengembangan potensi kemanusiaan secara utuh dan penanaman nilai-nilai sosial budaya yang diyakini oleh sekelompok masyarakat agar dapat mempertahankan hidup dan kehidupan secara layak. Sedangkan Menurut Hunderson dalam bukunya Uyoh Sadulloh (2010:5) menjelaskan bahwa Pendidikan merupakan suatu proses pertumbuhan dan perkembangan, sebagai hasil interaksi individu dengan lingkungan sosial dan lingkungan fisik, berlangsung sepanjang hayat sejak manusia lahir.

Anak adalah manusia kecil yang memiliki potensi yang masih harus dikembangkan. Dalam mengembangkan segala potensi yang dimiliki oleh anak, maka anak membutuhkan suatu pendidikan. Pendidikan anak usia dini adalah suatu upaya pembinaan yang ditujukan kepada anak sejak lahir sampai usia enam tahun. Hal tersebut merupakan upaya strategis untuk menyiapkan generasi bangsa yang berkualitas.

Pendidikan sendiri dalam arti luas dijelaskan oleh Henderson, menurutnya pendidikan merupakan suatu proses pertumbuhan dan perkembangan, sebagai hasil interaksi individu dengan lingkungan sosial dan lingkungan fisik, berlangsung sepanjang hayat sejak manusia lahir. Warisan sosial merupakan bagian dari lingkungan masyarakat, merupakan alat bagi manusia untuk pengembangan manusia yang baik dan inteligen, untuk meningkatkan kesejahteraan hidupnya (Uyoh Sadulloh, 2010:5). Selanjutnya dalam arti khusus, Langeveld mengemukakan bahwa pendidikan adalah bimbingan yang diberikan oleh orang dewasa kepada anak yang belum dewasa untuk mencapai kedewasaannya (Uyoh Sadulloh, 2010:3).

Berdasarkan Undang-Undang RI Nomor 23 Tahun 2002 Pasal 9 Ayat 1 tentang perlindungan anak dinyatakan bahwa setiap anak berhak memperoleh pendidikan dalam rangka pengembangan pribadinya dan tingkat kecerdasannya sesuai dengan minat dan bakatnya. Salah satu sikap dasar yang harus dimiliki anak untuk menjadi manusia yang baik adalah anak harus memiliki sikap dan nilai moral yang baik dalam berperilaku sebagai umat Tuhan, anggota keluarga dan anggota masyarakat. Pendidikan Anak Usia Dini adalah saat yang paling baik dan tepat untuk meletakkan dasar-dasar pendidikan nilai, moral, dan agama kepada anak. Walaupun peran orangtua sangatlah besar dalam membangun dasar moral dan agama bagi anak-anaknya, peran pendidik dalam Pendidikan Anak Usia Dini juga tidaklah kecil dalam meletakkan dasar moral dan agama bagi seorang anak (Hidayat, 2007:38).

Pentingnya pendidikan anak sejak usia dini juga didasarkan pada Undang-undang Nomor 20 tahun 2003 tentang sistem Pendidikan Nasional pasal 28 ayat 1 yang berbunyi "Pendidikan Anak Usia Dini diselenggarakan bagi anak sejak lahir sampai dengan enam tahun dan bukan merupakan prasyarat untuk mengikuti pendidikan dasar." Selanjutnya pada Bab 1 pasal 1 ayat 14 ditegaskan bahwa Pendidikan Anak Usia Dini adalah suatu upaya pembinaan yang ditujukan kepada anak sejak lahir sampai dengan usia enam tahun yang dilakukan melalui pemberian rangsangan pendidikan untuk membantu pertumbuhan dan perkembangan jasmani dan rohani agar anak memiliki kesiapan dalam memasuki pendidikan lebih lanjut.

Pendidikan nilai agama moral bagi anak erat kaitannya tentang perilaku seorang anak, sikap sopan santun, kemauan melaksanakan ajaran agama dalam kehidupan seharihari. Dengan nilai agama dan moral yang dimiliki bagi seorang anak diharapkan dapat membedakan perilaku baik dan buruk taat dalam menjalankan perintah agamanya dalam kehidupan. Pemahaman yang keliru yang diperoleh anak, serta anak-anak yang tidak memperoleh bimbingan dan arahan yang tepat dalam memahami sesuatu keadaan maka anak akan mempunyai persepsi yang keliru pula. Oleh karena itu perlu bimbingan dan arahan baik dari pendidik, orang tua maupun lingkungan masyarakatnya. 
Ketika rasa keagamaan itu sudah tumbuh pada diri anak, maka anak harus diberikan latihan-latihan keagamaan melalui kegiatan berdoa, beribadah serta berperilaku sesuai ajaran agama, sehingga diharapkan anak akan menjadi taat beribadah terhadap ajaran agamanya. Apabila latihan itu dilalaikan sejak kecil atau dengan cara yang kurang tepat, maka ketika mereka menginjak usia dewasa nanti tidak akan memiliki kepedulian yang tinggi pada kehidupan beragama dalam kesehariannya.

Anak merupakan generasi penerus bangsa, ditangan merekalah nasib suatu bangsa berada. Jika anak memiliki agama dan moral yang rendah nasib suatu bangsa itu akan mengalami kehancuran dan penuh dengan kriminalitas. Sebaliknya jika anak memiliki agama dan moral yang baik maka nasib bangsa itu akan maju dan tenteram. Untuk itu, anak perlu mendapatkan pendidikan yang baik sejak sedini mungkin sehingga anak akan tumbuh dan berkembang menjadi manusia yang memiliki kepribadian yang tangguh. Salah satu pendidikan yang diupayakan yaitu pendidikan agama dan moral. Pendidikan agama moral sangatlah penting bagi anak. Karena pendidikan agama moral merupakan salah satu aspek yang harus dikembangkan pada anak usia dini.

Usia dini merupakan periode awal yang paling penting dan mendasar dalam sepanjang rentang pertumbuhan serta perkembangan kehidupan manusia. Salah satu yang menjadi penciri masa usia dini adalah the golden ages atau periode keemasan. Dimana perkembangan kecerdasan pada masa ini mengalami peningkatan sampai 50\%. Pada masa ini mengalami pematangan fungsi-fungsi fisik dan psikis yang siap merespon stimulasi yang diberikan oleh lingkungan. Masa ini merupakan tempo untuk meletakkan dasar pertama dalam mengembangkan kemampuan fisik, kognitif, bahasa, seni, sosial emosional, disiplin diri, nilai-nilai agama, konsep diri dan kemandirian (Isjoni, 2011:19).

Pendidikan nilai-nilai moral dan keagamaan pada program Pendidikan Anak Usia Dini (PAUD) merupakan pondasi yang kokoh dan sangat penting keberadaannya, dan jika hal itu telah tertanam dengan pada usia sejak dini, hal tersebut merupakan awal yang baik bagi pendidikan anak bangsa untuk menjalani pendidikan selanjutnya. Pendidikan harus berprinsip pada pengembangan nilai-nilai moral dan agama sebagai upaya untuk mengantarkan anak didik menuju kedewasaan berpikir, bersikap, dan berperilaku secara terpuji (akhlak al-karimah). Upaya tersebut bisa dilakukan oleh para pendidik (guru dan orang tua) sejak usia dini, yakni ketika masa kanak-kanak. Selain itu, Islam juga sangat memperhatikan pendidikan anak dari sisi moral serta mengajarkan akan akhlak dan adat istiadat yang mulia.

Dalam pendidikan anak usia dini, salah satu kawasan yang harus dikembangkan adalah nilai moral, karena dengan diberikannya pendidikan nilai moral sejak usia dini ini diharapkan pada tahap perkembangan anak selanjutnya akan mampu membedakan baik buruk, benar salahmana yang harus mereka lakukan dan yang tidak perlu dilakukan. Sehingga, ia bisa menerapkannya dalam kehidupan sehari-hari yang akan berpengaruh pada mudah tidaknya anak diterima di masyarakat sekitarnya dalam hal bersosialisasi.

Adapun pendidikan agama moral yang diberikan pada masa usia dini berdasarkan Permendikbud No 137 Tahun 2014 tentang Standar Nasional Pendidikan Anak Usia dini. Dimana tingkat pencapaian perkembangan anak aspek nilai agama dan moral pada anak usia 4-5 tahun antara lain: mengetahui agama yang dianutnya, meniru gerakan beribadah dengan urutan yang benar, mengucapkan do'a sebelum dan/atau sesudah melakukan sesuatu, mengenal perilaku baik/sopan dan buruk, membiasakan diri berperilaku baik, mengucapkan salam dan membalas salam. Usia 5-6 tahun diantaranya: mengenal agama yang dianut, mengerjakan ibadah, berperilaku jujur, penolong, sopan, hormat, sportif, dsb, menjaga kebersihan diri dan lingkungan, mengetahui hari besar agama, menghormati (toleransi) agama orang lain. 
Dalam lembaga pendidikan anak usia dini, moral dan nilai-nilai agama ditanamkan antara lain melalui keteladanan dari guru maupun orangtua. Anak-anak cenderung meneladani gurunya. Dalam pepatah Jawa, guru adalah seseorang yang digugu dan ditiru. Guru merupakan teladan bagi murid-muridnya. Jika sang guru melakukan tindakan A, murid juga akan meniru melakukan tindakan yang sama. Pembelajaran akan berempati dan lebih bermakna apabila pendidik berusaha menghadirkan situasi nyata dalam bentuk kegiatan sehari-hari baik dirumah maupun disekolah. Proses pembelajaran tersebut ditanamkan secara terus menerus dan langsung melalui metode keteladanan yang dilakukan oleh guru. Dengan begitu diharapkan pembelajaran tersebut akan membawa pengaruh dalam perilaku anak sehari-hari.

Untuk dapat menciptakan anak yang shaleh dan shalehah, guru tidak cukup hanya memberikan prinsip saja, karena yang lebih penting bagi anak adalah figur yang memberikan keteladanan dalam menerapkan prinsip tersebut. Sehingga sebanyak apapun prinsip yang diberikan tanpa disertai dengan contoh teladan, ia hanya akan menjadi suatu kumpulan resep yang tidak ada maknanya. Perlunya pengembangan moral dan nilai-nilai agama sejak kecil yang dimulai pada anak usia dini, misalnya ketika guru atau orang tua membiasakan anakanaknya untuk berperilaku sopan seperti mencium tangan orang tua ketika berjabat tangan, mengucapkan salam ketika akan berangkat dan mau berbagi mainan, mau bekerja sama, tidak marah, mau memaafkan, maka dengan sendirinya perilaku seperti itu akan menjadi suatu kebiasaan mereka sehari-hari.

Berdasarkan hasil wawancara dengan Ibu Idatul lailis semani selaku guru kelas. Beliau menjelaskan bahwa nilai agama moral anak di Tk Al-Muhsin alhamdulillah sudah baik, akan tetapi namanya anak kecil masih terus untuk selalu diingatkan. Hal tersebut diatas dapat dibuktikan dari hasil observasi yang dilakukan bahwa terdapat adanya anak yang sudah hafal surat-surat pendek, serta do'a-doa seperti do'a waktu dhuha. Selain itu pembelajaran yang dilaksanakan oleh guru sudah aplikatif, terbukti dari adanya guru yang menjelaskan dan memberikan contoh untuk berbagi minuman ketika ada teman yang tidak membawa minum. Dengan melihat fenomena di atas, tertarik untuk melakukan penelitian dengan judul "Implementasi Pengembangan Nilai Agama Moral Pada Anak Usia Dini Melalui Metode Keteladanan Di Tk Al-Muhsin.

\section{METODE PENELITIAN}

Penelitian ini menggunakan pendekatan kualitatif, sehingga data yang dipaparkan dalam penelitian ini tidak berupa angka-angka, tetapi berupa uraian kata-kata. Sebagaimana lazimnya penelitian kualitatif, penelitian ini tidak dimaksudkan untuk menguji hipotesis yang telah dirumuskan, tetapi lebih berorientasi pada pengembangan dan pengetahuan baru yang diperoleh melalui pengamatan, wawancara, dan studi dokumentasi yang berkaitan langsung dengan pokok permasalahan.

Adapun yang dimaksud dengan metode kualitatif adalah metode (jalan) penelitian yang sistematis yang digunakan untuk mengkaji atau meneliti suatu objek pada latar alamiah tanpa ada manipulasi didalamnya dan tanpa ada pengujian hipotesis, dengan metode-metode yang alamiah ketika hasil penelitian yang diharapkan bukanlah generalisasi berdasarkan ukuran-ukuran kuantitas, namun makna (segi kualitas) dari fenomena yang diamati (Andi Prastowo, 2014:24).

\section{HASIL DAN PEMBAHASAN}

Untuk mengetahui implementasi pengembangan nilai agama moral pada anak usia dini melalui metode keteladanan di TK Al-Muhsin Tagangser Daya, Pasean, Pamekasan, saya mengadakan wawancara dengan Ibu Idatul Lailis Semani selaku guru kelas. Beliau menjelaskan bahwa pelaksanaan pembelajaran nilai agama moral dilakukan setiap hari, waktu pembukaan, di inti serta pada waktu akhir pembelajaran. Kalau didalam inti 
pembelajaran biasanya memberi tanda cek pada perbuatan baik dan tidak baik. Dengan guru mendemonstrasikan, mencontohkan dahulu kemudian anak-anak menirukan. Penjelasan dari ibu Idatul Lailis Semani diatas juga dikuatkan oleh Ibu Endang Maimunah selaku guru pendamping bahwa nilai agama moral di TK Al-Muhsin Tagangser Daya, Pasean, Pamekasan dilaksanakan setiap saat dan setiap waktu. Tidak melihat itu pembelajaran pembuka, inti, istirahat, maupun penutup. Karna aspek nilai agama moral sangat penting dan menjadi pondasi anak berpikir bahwa Allah itu ada dan selalu melihat semua yang kita lakukan, dan Bpk Molyadi SPd selaku kepala sekolah TK Al-Muhsin Tagangser Daya, Pasean, Pamekasan. Beliau menyatakan bahwa pembelajaran nilai agama moral untuk anak dilakukan setiap waktu dan sebenarnya ada target tersendiri dan target tersebut tidak ditulis. Seperti setiap hari itu berdo'a, sholat, sopan santun, tingkah laku dan karakter harus ada. Jika anak misalnya dirumah itu kebiasaannya kurang baik dan kurang sopan, itu tugasnya guru untuk bisa merubah. Hal tersebut dapat dibuktikan dari adanya hasil observasi yang dilakukan oleh saya di ruang kelas bahwa nilai agama moral dilaksanakan dalam pembelajaran mulai dari kegiatan pembuka, kegiatan inti sampai dengan kegiatan akhir dengan guru memberikan contoh dan siswa menirukannya. Berdasarkan hasil wawancara dan observasi diatas, dapat disimpulkan bahwa implementasi pengembangan nilai agama moral pada anak usia dini dilakukan setiap saat, baik itu pada kegiataan awal, kegiatan inti, istirahat maupun pada kegiatan akhir dengan adanya contoh dari guru dan siswa menirukannya.Untuk mengetahui lebih jelasnya mengenai bagaimana implementasi nilai agama moral pada anak usia dini melalui metode keteladanan dapat diuraikan sebagai berikut:

Keteladanan Hafalan surat-surat pendek dan do'a-do'a harian Sebagaimana penjelasan dari Ibu Idatul Lailis Semani selaku guru. Beliau menjelaskan bahwa salah satu contoh yaitu hafalan surat-surat pendek dan do'a-do'a harian yang dilakukan secara bersama-sama setiap hari pada awal inti dan akhir kegiatan dengan guru memberikan contoh dan anak menirukan. Hal diatas diperkuat oleh penjelasan Endang Maimunah selaku guru pendamping. Beliau menyatakan bahwa setiap hari dilakukan hafalan surat-surat pendek dan do'a-do'a harian. Biasanya dilakukan pada awal kegiatan dengan guru melafalkan dulu kemudian anak-anak mengikutinya. Berdasarkan hasil wawancara dan observasi diatas dapat disimpulkan bahwa terdapat adanya keteladanan yang dilakukan oleh guru berupa menghafal surat-surat pendek dan do'a-do'a harian disetiap harinya dengan guru melafalkan ayatnya terlebih dahulu kemudia anak-anak mengikutinya.

Keteladanan Praktek sholat dhuha yang dilakukan oleh guru dengan mengajak serta murid-murid Sebagaimana yang dikatakan oleh Idatul Lailis Semani selaku guru. Beliau menjelaskan bahwa adanya praktik sholat dhuha yang ditargetkan dilakukan setiap hari diruang kelas secara bersama-sama dengan dipimpin oleh guru. Dengan adanya praktek sholat dhuha ini diharapkan sebagai tempat bagi anak-anak untuk berlatih melakukan sholat dengan gerakan dan bacaannya yang benar. Hal tersebut dikuatkan oleh penjelasan dari Bpk Molyadi Spd selaku kepala sekolah TK Al-Muhsin Tagangser Daya, Pasean, Pamekasan, Beliau menjelaskan bahwa sebenarnya setiap hari ada praktik sholat dhuha yang dilakukan oleh guru dengan mengajak beserta murid-murid diruang kelas. Akan tetapi terkadang terkendala dengan adanya kegiatan-kegiatan yang lain Berdasarkan hasil wawancara dan observasi yang diperoleh diatas maka dapat disimpulkan bahwa adanya keteladanan berupa sholat dhuha yang dilakukan guru dengan mengajak murid-murid untuk melakukan sholat bersama-sama diruang sekolah dengan catatan guru sedang tidak halangan atau ada kegiatan yang lain.

Keteladanan Sopan santun dalam berkata dan bersikap kepada orang yang lebih tua Sebagaimana penjelasan dari Ibu Idatul Lailis Semani selaku guru. Beliau menjelaskan bahwa adanya keteladanan sikap seperti membungkukkan badan ketika lewat didepan orang 
tua, dan perkataan seperti berkata yang halus, tidak membentak-bentak kepada orang yang lebih tua. Biasanya dengan guru memberikan contoh terlebih dahulu kemudian anak-anak menirukannya. Hal tersebut diatas diperkuat dari adanya hasil observasi yang menunjukkan bahwa adanya pembelajaran mengenai berkata yang sopan seperti enggeh, mboten, dan sebagainya kepada orang yang lebih tua dengan menggunakan bahasa daerah setempat. Berdasarkan hasil wawancara dan observasi diatas dapat disimpulkan bahwa guru memberikan contoh keteladanan berupa berkata yang sopan kepada orang yang lebih tua.

Keteladanan Meminta maaf ketika berbuat salah Sebagaimana penjelasan dari Ibu Idatul Lailis Semani selaku guru menjelaskan bahwa anak dilatih untuk meminta maaf kepada teman. Biasanya pada saat bermain ada anak yang rebutan mainan sehingga terkadang anak yang menangis atau bertengkar, dan salah satu dari mereka tidak ada yang mau meminta maaf. Pada saat itu kita minta anak untuk saling bersalaman dan kita memberikan contoh perkataan cara meminta maaf yang baik kepada teman Hal tersebut diperkuat dengan adanya penjelasaan dari Ibu Endang Maimunah selaku guru pendamping yang menjelaskan bahwa biasanya kita meminta anak untuk bersalaman ketika ada anak yang bertengkar. Kita memberikan contoh cara meminta maaf yang baik karena biasanya anak meminta maafnya masih kurang baik. Hal tersebut diatas diperkuat dengan adanya penjelasan dari Bpk Molyadi Spd selaku kepala sekolah TK Al-Muhsin Tagangser Daya, Pasean, Pamekasan yang menjelaskan bahwa anak itu kan sifatnya egois. Jadi terkadang kita masih memberikan contoh untuk meminta maaf yang baik kepada teman Berdasarkan hasil wawancara dan observasi yang diperoleh diatas, maka dapat disimpulkan bahwa terdapat adanya contoh meminta maaf yang baik kepada teman yang diberikan oleh guru pada saat ada anak berbuat salah atau bertengkar dengan temannya.

Keteladanan Mengucapkan "tolong" dalam meminta bantuan Sebagaimana penjelasana dari Ibu Idatul Laisis Semani selaku guru kelas. Beliau menjelaskan bahwa pada saat kita membutuhkan bantuan orang lain hendaknya kita sertai dengan kata "tolong" meskipun kita meminta tolongnya kepada anak-anak atau orang yang lebih muda dari kita. Contohnya seperti kita meminta anak untuk membunagkan sampah maka perintahnya bukan "buangkan sampah itu!" melainkan "mas/mbak tolong buangkan sampah itu!" Berdasarkan hasil wawancara dan observasi yang diperoleh diatas, dapat disimpulkan bahwa terdapat contoh dari guru pada saat meminta bantuan disertai dengan kata "tolong".

Keteladanan Mengucapkan salam dan berjabat tangan ketika bertemu Sebagaimana penjelasan yang disampaikan oleh Ibu Idatul Lailis Semani selaku guru kelas. Beliau menjelaskan bahwa setiap hari setibanya disekolah guru berjabat tangan dan mengucapkan salam dengan sesama guru, dan tidak hanya sesama guru saja tetapi juga dengan orang tua wali murid serta murid-murid yang lain Hal tersebut diperkuat dengan adanya penjelasan dari Bpk Molyadi Spd selaku kepala sekolah TK Al-Muhsin Tagangser Daya, Pasean, Pamekasan Beliau menjelaskan bahwa penanaman nilai agama moral tidak hanya praktek sholat dhuha saja, akan tetapi adanya salaman sesama guru, guru dengan orang tua wali murid dan mengucap salam setiap pagi hari ketika sesampainya di sekolah juga merupakan salah satu contoh dari penanaman nilai agama moral Berdasarkan hasil wawancara dan observasi yang diperoleh diatas, maka dapat disimpulkan bahwa terdapat adanya contoh yang diberikan oleh guru berupa mengucapkan salam dan berjabat tangan ketika bertemu dan setibanya disekolah.

\section{KESIMPULAN}

Berdasarkan hasil penelitian dan pembahasan implementasi pengembangan nilai agama moral pada anak usia dini melalui metode keteladanan di TK Al-Muhsin Tagangser Daya, Pasean, Pamekasan maka dapat diambil kesimpulan sebagai berikut: Metode keteladan Hafalan surat pendek dan doa-doa harian, Praktek sholat dhuha yang dilakukan 
oleh guru dengan mengajak serta murid-murid, Sopan santun dalam berkata dan bersikap kepada orang yang lebih tua, dan Metode keteladan Meminta maaf ketika berbuat salah, Mengucapkan "tolong" dalam meminta bantuan, Mengucapkan salam dan berjabat tangan ketika bertemu

\section{DAFTAR PUSTAKA}

Ahmad Susanto. 2011. Perkembangan Anak Usia Dini Pengantar Dalam Berbagai Aspeknya. Jakarta: Kencana Prenada Media Group

Desmita. 2011. Psikologi Perkembangan Peserta Didik. Bandung: Remaja Rosdakarya.

Djam'an Satori dan Aan Komariah. 2014. Metodologi Penelitian Kualitatif. Bandung: Alfabeta.

Isjoni. 2011. Model Pembelajaran Anak Usia Dini. Bandung: Alfabeta

Kemendikbud. 2013. Konsep Dasar Pendidikan Anak Usia Dini. Jakarta: Kemendikbud.

2013. Pengembangan 5 Aspek kemampuan Anak Usia Dini. Jakarta: Kemendikbud.

Lexy J.Moleong. 2014. Metodologi Penelitian Kualitatif. Bandung: Remaja Rosdakarya.

Otib Satibi Hidayat. 2008. Metode Pengembangan Moral Dan Nilai-Nilai Agama. Jakarta: Universitas Terbuka.

Winda Gunarti. 2008. Metode Pengembangan Perilaku Dan Kemampuan Dasar AUD. Jakarta: Universitas Terbuka. www.mahsun.net/2016/08/macam-macam-metodeketeladanan.html (diakses pada tanggal 02 Mei 2017, pukul 20:00 WIB)

Asti Inawati. 2017. Strategi Pengembangan Moral dan Nilai Agama Untu Anak Usia Dini, Jurnal Pendidikan Anak, Vol. 3 No. 1

Lawrence Kholbergh. 1979. The claim to moral adequacy of a highest judgment. The journal of philosophy, Vol.70 No.18 stage of moral

Machsunah, Yayuk Chayatun. 2017. Penanaman Pendidikan Karakter Melalui Keteladanan Pendidik (Studi Kasus Di Lbb Taman Pintar: Sahabat Sekolah Anak Lamongan). Journal Stkip Pgri Lamongan, Vol.1 No.2

Sabi'ati, Amin. 2016. Membangun Karakter Aud Dalam Pengembangan Nilai Agama Dan Moral Di Ra Masyithoh Pabelan Kab. Semarang. Al Athfal: jurnal pendidikan Anak, Vol.2 No.4

William C Campbell, Frank J Cavico, Pedro F. Pellet, Bahaudin J. Mubtaja,. 2010. Applying Moral Development Literature And Aethnical Theories To Administration of Taxes In Kosovo, Internasional Business and Economics Research Journal, Vol. 9, No. 7

Hafsah Sitompul 2006 Metode Keteladanan dan Pembiasaan Jurnal Darul 'Ilmi Vol. 04, No. 01 Januari 2016.

Ariffiana Zelvi, 2017. Proses Penanaman Nilai-Nilai Agama Pada Anak Usia Dini Dalam Keluarga Di Kampung Gambiran Pandeyan Umbulharjo Yogyakarta, Jurnal. Pendidikan Anak Usia Dini Edisi 1 Tahun ke-6 2017, diakses September 2018.

Muhammad Ali Saputra, (2014), Menanaman Nilai-Nilai Agama Pada Anak Usia Dini Di R.A. di Addariyah Kota Palopo, Jurnal. Diakses September, 2018. 